\title{
First record of the white shark Carcharodon carcharias (Lamniformes: Lamnidae) from Sabah, Malaysian Borneo
}

\author{
Clinton AJ Duffy ${ }^{1,2}$
}

\begin{abstract}
Background: Although widespread and intensively studied in the Southwest and Northeast Pacific Ocean, relatively little is known of the distribution and biology of the white shark (Carcharodon carcharias) Northwest Pacific.

Results and conclusions: Three underwater photographs of a large white shark taken near the St. Joseph oil field, Sabah, in 1981 represent the first confirmed record of the species from Borneo. This record and one from Lombok Strait suggest that white sharks may move between Northwest Pacific and Indian Oceans across the Sunda Shelf.
\end{abstract}

Keywords: Carcharodon carcharias, White shark, Sabah, South China Sea

\section{Background}

The white shark (Carcharodon carcharias) has been recorded from sub-polar to tropical waters worldwide (Compagno 2001; Bonfil et al. 2005; Duffy et al. 2012). Although intensively studied in the Southwest and Northeast Pacific Ocean, relatively little is known of the species in the Northwest Pacific (Compagno 2002; Bruce et al. 2006; Domeier 2012; Duffy et al. 2012). Christiansen et al. (2014) reviewed 240 observations of white sharks from the Northwest Pacific concluding that although the species is not abundant, it is present in the region year round. The northernmost record of the species from the Northwest Pacific is from Tatar Strait, Sakhalin, Russia $\left(47^{\circ} 19.45^{\prime} \mathrm{N}, 141^{\circ} 25.74^{\prime} \mathrm{E}\right)$, the southernmost is from the Bohol Sea, Philippines (c. $8^{\circ} 39.66^{\prime} \mathrm{N}, 124^{\circ} 37.33^{\prime} \mathrm{E}$ ) (Herre 1953, Christiansen et al. 2014). In early 1981 a large white shark (Carcharodon carcharias) was photographed by commercial divers while laying an underwater pipeline from the barge E.T.P.M. DLB801 near the St Joseph offshore oil field, Sabah. This represents the first record of a white shark from Borneo. This note provides details of the sighting and reproduces one of

Correspondence: cduffy@doc.govt.nz

${ }^{1}$ Institute of Marine Science, University of Auckland, Private Bag 92019, Auckland 1142, New Zealand

${ }^{2}$ Department of Conservation, Private Bag 68908, Newton, Auckland 1145 , New Zealand the photographs, confirming identification of the shark as C. carcharias.

\section{Methods}

Details of the sighting were obtained in an interview with one of the divers involved on 11 January 2015. The dates and approximate location that the barge was working in were confirmed by reference to the diver's commercial dive log, and three underwater photographs of the shark were examined. The largest, a $203 \times 254 \mathrm{~mm}$ print mounted on board, was photographed using a digital camera (Fig. 1).

\section{Results}

The St. Joseph oil field is located in the South China Sea about $35 \mathrm{~km}$ off the coast of Usukan Bay, Sabah $\left(6^{\circ}\right.$ $35.677^{\prime} \mathrm{N}, 116^{\circ} 7.180^{\prime}$ E) (Fig. 2). Water depth varies from $27 \mathrm{~m}$ to $43 \mathrm{~m}$ (Johnson et al. 1989). Sea surface temperature (SST) during April and May is $28-29{ }^{\circ} \mathrm{C}$ (Huang and Fang 1998, http://envf.ust.hk/satop/southchina-sea.html; Gordon et al. 2003).

The shark was observed from the barge over a period of about two days sometime between 12 April and 5 May 1981. Two of the photographs show the right side and ventral aspect of shark's head from the snout to just posterior to the lower jaw. The third is shown in Fig. 1. Diagnostic characters visible in Fig. 1 are the heavy, muscular body; relatively short, bluntly conical snout; 


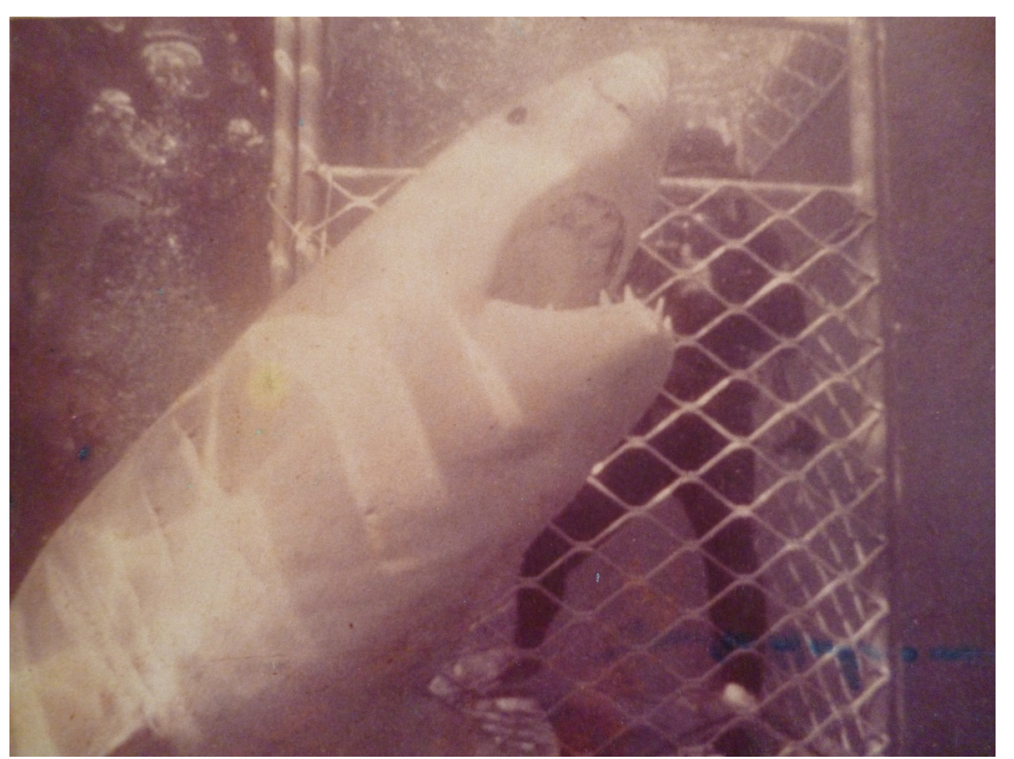

Fig. 1 Large white shark (Carcharodon carcharias) photographed near the St Joseph offshore oil field, Sabah, Malaysian Borneo, April-May 1981 (Image: courtesy of Glen Ladkin, Pacific Diving)

large, black eye; five large gill slits located anterior to the pectoral fin base; and the large, triangular anterior teeth in the lower jaw. The diver estimated the shark to be $22 \mathrm{ft}(6.7 \mathrm{~m})$ total length $(\mathrm{TL})$ by comparing it to a $12.2 \mathrm{~m}$ section of pipe. It was not possible to independently estimate the shark's length from any of the photographs because it was always pictured some distance in front of any objects that could have been used for scale. The sex of the shark is unknown.

\section{Discussion}

As well as being the first record of Carcharodon carcharias from Borneo, this represents the southernmost confirmed record of the species from the Northwest Pacific Ocean (Fig. 2). Carcharodon carcharias is widely distributed in the South China Sea (Compagno 2002; Compagno et al. 2005; Christiansen et al. 2014). Christiansen et al. (2014) most southerly records were two reports from Qui Nhon Bay, Vietnam, and one from the Philippines. One of the Vietnamese records was an unconfirmed media report of a $1.6 \mathrm{~m}$ TL juvenile, whereas the other was of a $5 \mathrm{~m}$ TL specimen (unknown sex) that was confirmed by a photograph (http://www. elasmollet.org/Cc/Cc_list.html). The record from the Philippines was based upon a media report of several purported sightings of C. carcharias near the towns of Limay and Orion, Manila Bay (Cervantes 2003). That report also included reference to an attack on a fisher by C. carcharias off Barangay Luz, Cebu Island; the capture of a $6 \mathrm{~m}$ pregnant female near Limay in April 2003; and sightings off Palawan and Mindanao (Cervantes 2003). Herre (1953) reported C. carcharias from Malampaya
Sound, Palawan, and the Bohol Sea off Misamis Oriental, Mindanao (Fig. 2). Compagno et al. (2005) found no confirmed contemporary records of $C$. carcharias from the Philippines but commented these are to be expected given the species' wide distribution in tropical waters.

Although the generally accepted maximum size of $C$. carcharias is $6.4 \mathrm{~m} \mathrm{TL}$, there are plausible reports of individuals up to $7.0 \mathrm{~m}$ TL (Mollet et al. 1996; Compagno 2001). As female $C$. carcharias are generally larger than males, the Sabah shark was probably a mature female. The maximum size of male $C$. carcharias is generally accepted to be $5.1 \mathrm{~m} \mathrm{TL}$, possibly $5.5 \mathrm{~m}$ TL (Compagno 2001). Fahmi and Dharmadi (2014) reported the capture of a $6.6 \mathrm{~m}$ TL male $C$. carcharias off Dompu, Lombok Strait, Indonesia $\left(08^{\circ} 51^{\prime} \mathrm{S}, 118^{\circ} 18^{\prime} \mathrm{E}\right)$ in July 2013 (Fig. 2). However, this shark had been cut into five pieces for transport prior to measurement and it may have been less than or equal to $6 \mathrm{~m}$ TL (Fahmi, LIPI, pers. comm.).

The occurrence of C. carcharias off Sabah in AprilMay is consistent with the seasonal movements of the species in the Northwest Pacific inferred by Christiansen et al. (2014). They reported C. carcharias during all months except July-August in the south (China, Taiwan, Philippines, and Vietnam), and all months except October-January in the north (Russia and Republic of Korea). This is similar to the seasonal movements of $C$. carcharias in the Northeast Pacific, Southwest Pacific and North Atlantic Oceans (Casey and Pratt 1985; Bruce et al. 2006; Jorgensen et al. 2009; Duffy et al. 2012). In these regions juvenile and adult white sharks tend to undertake rapid, directed movements from temperate to 


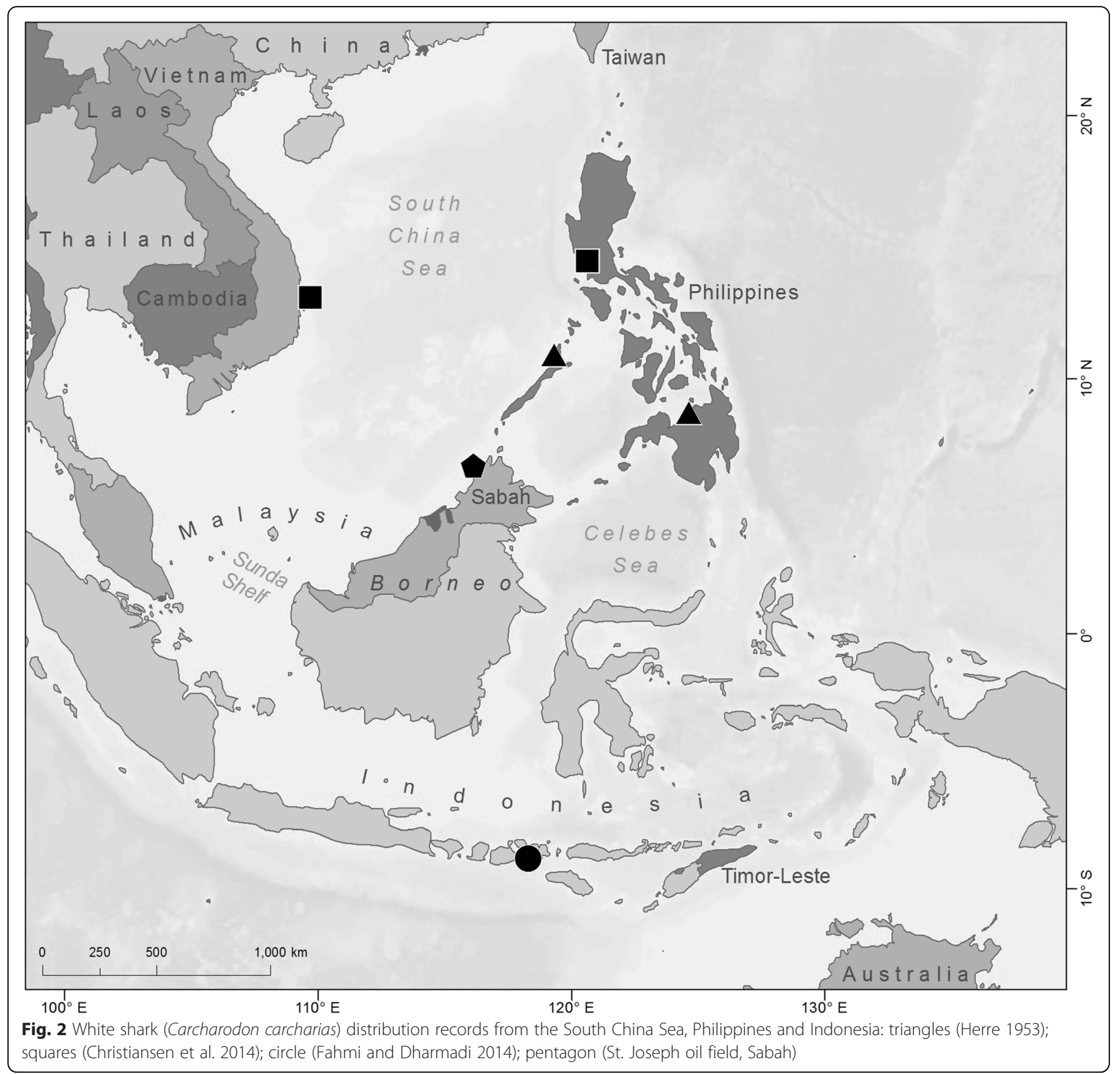

subtropical and tropical waters in the autumn and winter, returning to inshore temperate habitats in the spring and early summer.

\section{Conclusion}

The occurrence of Carcharodon carcharias in the southern South China Sea during the Northern Hemisphere Spring is confirmed by three underwater photographs of a large C. carcharias taken near the St. Joseph oil field, Sabah, in 1981. Although the seasonal movements of Northern and Southern Hemisphere populations are out of phase, the presence of $C$. carcharias on the Sunda Shelf and in Lombok Strait suggests dispersal between the Northwest Pacific and Indian Ocean populations may occur through the Java Sea and Sunda Islands.

\section{Acknowledgements}

I would like to thank Glen Ladkin, Pacific Diving, Tauranga, New Zealand, for providing details of the white shark encountered off Sabah, as well as access to his dive log and photo album. Dr Fahmi, Indonesian Institute of Sciences $(\mathrm{LIPI})$, provided advice on the reliability of the length measurement of the Dompu white shark. Figure 2 was prepared by Geraldine Moore, New Zealand Department of Conservation, using data sourced from ESRI, USGS and NOAA. Funding was provided by New Zealand Oil \& Gas Ltd (University Project Number: 3703064).

\section{Competing interests}

The author declares that he has no competing interests. 


\section{Authors' contributions}

CD interviewed Glen Ladkin on 11 January 2015, examined Mr Ladkin's dive $\log$ and photographs of the shark, reviewed the relevant literature, and prepared the manuscript and Fig. 1.

Received: 9 May 2015 Accepted: 25 February 2016

Published online: 04 July 2016

\section{References}

Bonfil R, Meÿer M, Scholl MC, Johnson R, O'Brien S, Oosthuizen H, Swanson S, Kotze D, Paterson M. Transoceanic migration, spatial dynamics and population linkages of white sharks. Science. 2005;310:100-3.

Bruce BD, Stevens JD, Malcolm H. Movements and swimming behaviour of white sharks (Carcharodon carcharias) in Australian waters. Marine Biology. 2006:150:161-72.

Casey JG, Pratt Jr HL. Distribution of the white shark, Carcharodon carcharias, in the western North Atlantic. In: Sibley G, Seigel JA, Swift CC, editors. Biology of the White Shark, Memoirs of the Southern California Academy of Sciences, vol. 9. 1985. p. 2-14.

Cervantes D. Man-eating white sharks sighted off Bataan. The Philippine Star, May 24, 2003. http://www.philstar.com/nation/207333/man-eating-whitesharks-sighted-bataan. Accessed 2 Apr 2015.

Christiansen HM, Lin V, Tanaka S, Velikanov A, Mollet HF, Wintner SP, Fordham SV, Fisk AT, Hussey NE. The Last Frontier: Catch Records of White Sharks (Carcharodon carcharias) in the Northwest Pacific Ocean. PLoS ONE. 2014; 9(4):e94407. doi:10.1371/journal.pone.0094407.

Compagno LJV. Sharks of the world: An illustrated and annotated catalogue of shark species known to date. Volume 2. Bullhead, mackerel and carpet sharks (Heterodontiformes, Lamniformes and Orectolobiformes), FAO Species Catalogue for Fishery Purposes No. 1. Rome: FAO; 2001.

Compagno LJV. Review of the Biodiversity of Sharks and Chimaeras in the South China Sea and Adjacent Areas. In: Fowler SL, Reed TM, Dipper FA, editors. Elasmobranch Biodiversity, Conservation and Management: Proceedings of the International Seminar and Workshop, Sabah, Malaysia, July 1997. Gland, Switzerland and Cambridge, UK: IUCN; 2002. p. 52-63.

Compagno LJV, Last PR, Stevens JD, Alava MNR. Checklist of Philippine Chondrichthyes, CSIRO Marine Laboratories Report 243. Hobart: CSIRO; 2005.

Domeier ML. A new life-history hypothesis for white sharks, Carcharodon carcharias, in the Northeastern Pacific. In: Domeier ML, editor. Global Perspectives on the Biology and the Life History of the White Shark. Boca Raton: CRC Press; 2012. p. 199-223.

Duffy CAJ, Francis MP, Manning MJ, Bonfil R. Regional population connectivity, oceanic habitat, and return migration revealed by satellite tagging of white sharks, Carcharodon carcharias, at New Zealand aggregation sites. In: Domeier ML, editor. Global Perspectives on the Biology and the Life History of the White Shark. Boca Raton: CRC Press; 2012. p. 301-18.

Fahmi, Dharmadi. First confirmed record of the white shark Carcharodon carcharias (Lamniformes: Lamnidae) from Indonesia. Marine Biodiversity Records. 2014;7:e53. doi:10.1017/S1755267214000414. 3pp.

Gordon AL, Dwi Susanto R, Vranes K. Cool Indonesian throughflow as a consequence of restricted surface layer flow. Nature. 2003;425(23):824-8.

Herre AWCT. Check list of Philippine fishes. US Fisheries and Wildlife Service Research Report. 1953;20:1-977.

Huang W, Fang M. Cover: Monthly composites of sea surface temperature of the South China Sea. International Journal of Remote Sensing. 1998;19:2435-8.

Johnson HD, Chapman JW, Ranggon J. Structural and stratigraphic configuration of the late Miocene Stage IVC reservoirs in the St. Joseph field, offshore Sabah, NW Borneo. Bulletin of the Geological Society of Malaysia. 1989:25:79-118.

Jorgensen SJ, Reeb CA, Chapple TK, Anderson S, Perle C, Van Sommeran SR, Fritz-Cope C, Brown AC, Klimley AP, Block BA. Philopatry and migration of Pacific white sharks. Proceedings of the Royal Society B Biological Sciences. 2009;277:679-88

Mollet HF, Cailliet GM, Klimley AP, Ebert DA, Testi AD, Compagno LV. A review of length validation methods and protocols to measure large white sharks. In: Klimley AP, Ainley DG, editors. Great white sharks: the biology of Carcharodon carcharias. Academic Press: San Diego; 1996. p. 91-108.

\section{Submit your next manuscript to BioMed Central and we will help you at every step:}

- We accept pre-submission inquiries

- Our selector tool helps you to find the most relevant journal

- We provide round the clock customer support

- Convenient online submission

- Thorough peer review

- Inclusion in PubMed and all major indexing services

- Maximum visibility for your research

Submit your manuscript at www.biomedcentral.com/submit
Biomed Central 